$10-1951$

\title{
Range And Habitat Of The Clam Polymesoda-caroliniana (Bosc) In Virginia (Family Cycladidae)
}

Jay D. Andrews

Virginia Fisheries Laboratory

Catherine Cook

Follow this and additional works at: https://scholarworks.wm.edu/vimsarticles

Part of the Marine Biology Commons

\section{Recommended Citation}

Andrews, Jay D. and Cook, Catherine, Range And Habitat Of The Clam Polymesoda-caroliniana (Bosc) In Virginia (Family Cycladidae) (1951). Ecology, 32(4), 758-760.

$10.2307 / 1932745$

This Article is brought to you for free and open access by the Virginia Institute of Marine Science at W\&M ScholarWorks. It has been accepted for inclusion in VIMS Articles by an authorized administrator of W\&M ScholarWorks. For more information, please contact scholarworks@wm.edu. 


\section{WILEY}

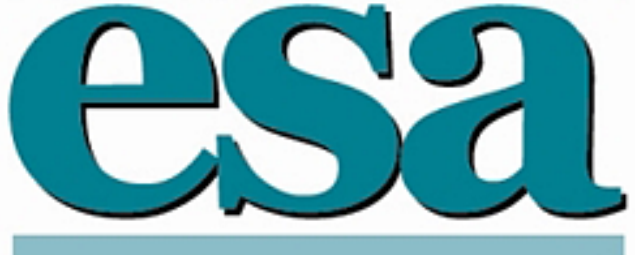

Range and Habitat of the Clam Polymesoda Caroliniana (Bosc) in Virginia (Family Cycladidae) Author(s): Jay D. Andrews

Source: Ecology, Vol. 32, No. 4 (Oct., 1951), pp. 758-760

Published by: Wiley on behalf of the Ecological Society of America

Stable URL: https://www.jstor.org/stable/1932745

Accessed: 07-10-2019 16:09 UTC

JSTOR is a not-for-profit service that helps scholars, researchers, and students discover, use, and build upon a wide range of content in a trusted digital archive. We use information technology and tools to increase productivity and facilitate new forms of scholarship. For more information about JSTOR, please contact support@jstor.org.

Your use of the JSTOR archive indicates your acceptance of the Terms \& Conditions of Use, available at https://about.jstor.org/terms extend access to Ecology 
Coe, W. R. 1938. Primary sexual phases in the oviparous oyster (Ostrea virginica). Biol. Bull., 74 (1) : 64-75.

Hopkins, A. E. 1931. Factors influencing the spawning and setting of oysters in Galveston Bay, Tex. Bull. U. S. Bur. of Fish., 47 (3) : 57-83.

Korringa, P. 1949. More light upon the problem of the oyster's nutrition? Bijdragen tot de Dierkunde, 28: 237-248.

Loosanoff, Victor L. 1932. Observations on propagation of oysters in James and Corrotoman Rivers and the Seaside of Virginia. The Virginia Commission of Fisheries, Newport News, Va.
- 1949. Variations in intensity of setting of oysters in Long Island Sound. Convention Addresses Nat. Shellfisheries Assoc., 1949. [Processed.]

Loosanoff, V. L., and C. A. Nomejko. 1951. Spawning and setting of the American oyster, $O$. Virginica, in relation to lunar phases. Ecology, 32 (1) : 113-134.

Needler, Alfreda Berkeley. 1932. Sex reversal in Ostrea virginica. Contr. Canadian Biol. and Fish., 7: 285-294.

Jay D. Andrews

Virginia Fisheries Laboratory Gloucester Point, Virginia

\section{RANGE AND HABITAT OF THE CLAM POLYMESODA CAROLINIANA (BOSC) IN VIRGINIA (FAMILY CYCLADIDAE) ${ }^{1}$}

The clam Polymesoda caroliniana (Bosc), which ranges north and eastward in brackish waters from Lavaca Bay, Texas, ${ }^{2}$ has not previously been reported north of the Neuse River, N. C. (Van der Schalie 1933). On 7 April 1947, Richard Hoffman found several shells on the beach above Swann Point on the James River, a tributary of Chesapeake Bay (Fig. 1). On 20 April 1947, J. P. E. Morrison (personal communication) and Hoffman found living specimens in the mud and detritus around the knees of cypress trees one-half mile above Swann Point. These records are included in this paper through the courtesy of Dr. Morrison of the U. S. National Museum.

In the spring of 1949 , the authors made several field trips to determine the distribution and habitat of the species in Tidewater Virginia. Figure 1 shows the areas visited and the places where Polymesoda was found. On the north bank of the James, clams have been found from slightly above Jamestown Island to the lower end of Mulberry Island, a distance of 17 nautical miles by river. The salinity range in this area varies from nearly fresh water at Jamestown to about 15 parts per thousand at river stations opposite the tip of Mulberry Island. Table I gives the number, average length, and range in length of clams collected at each station. All clams in each collection were measured. These collections are deposited at the U. S. National Museum.

\footnotetext{
1 Contributions from the Virginia Fisheries Laboratory, No. 35.

2 Dr. J. P. E. Morrison states that the specimens in the United States National Museum from Vera Cruz and Tampico, Mexico, belong to the closely related species $P$. triangula (Von dem Busch) (personal communication).
}

Polymesoda has not been found in the York River but several potential habitats remain to be examined.

\section{Description of Habitats}

Polymesoda is apparently restricted to intertidal habitats in the James River. Most clams have been found in a strip between mean low tide and one foot above this level. A careful search has failed to reveal the presence of this species either below the low water line or on oyster bars in the vicinity of known habitats.

These brackish-water clams have been found in three apparently diverse habitats :

1. Open river shores with eroding, sedgematted banks. Polymesoda were found in small protected crevices and often in the bottom of small depressions partially filled with finely divided plant debris and black mud. The clams were in depressions at a level six inches below the bases of living plants (Panicum and Juncus) but usually imbedded in a substratum well matted by the roots of dead plants. Stations (see Fig. 1): Mouth of Back River at Jamestown (4); Treasure Island (5); Mouth of Skiffes Creek (7); Lower Mulberry Island (10).

2. Under thick algal carpets on muddy banks of tidal creeks. Clams were found under small bulges in a thick cohesive carpet of algae covering muddy flats. This was a most remarkable habitat, for the algal mat was onequarter to one-fifth of an inch thick and probably had resulted from several seasons' growth. This implies that the larvae or young clams penetrated the mat and flourished under it, for clams of greatly varying sizes were found here. Small clams were abundant only in this habitat. The soil under the algal blanket was a fine black 


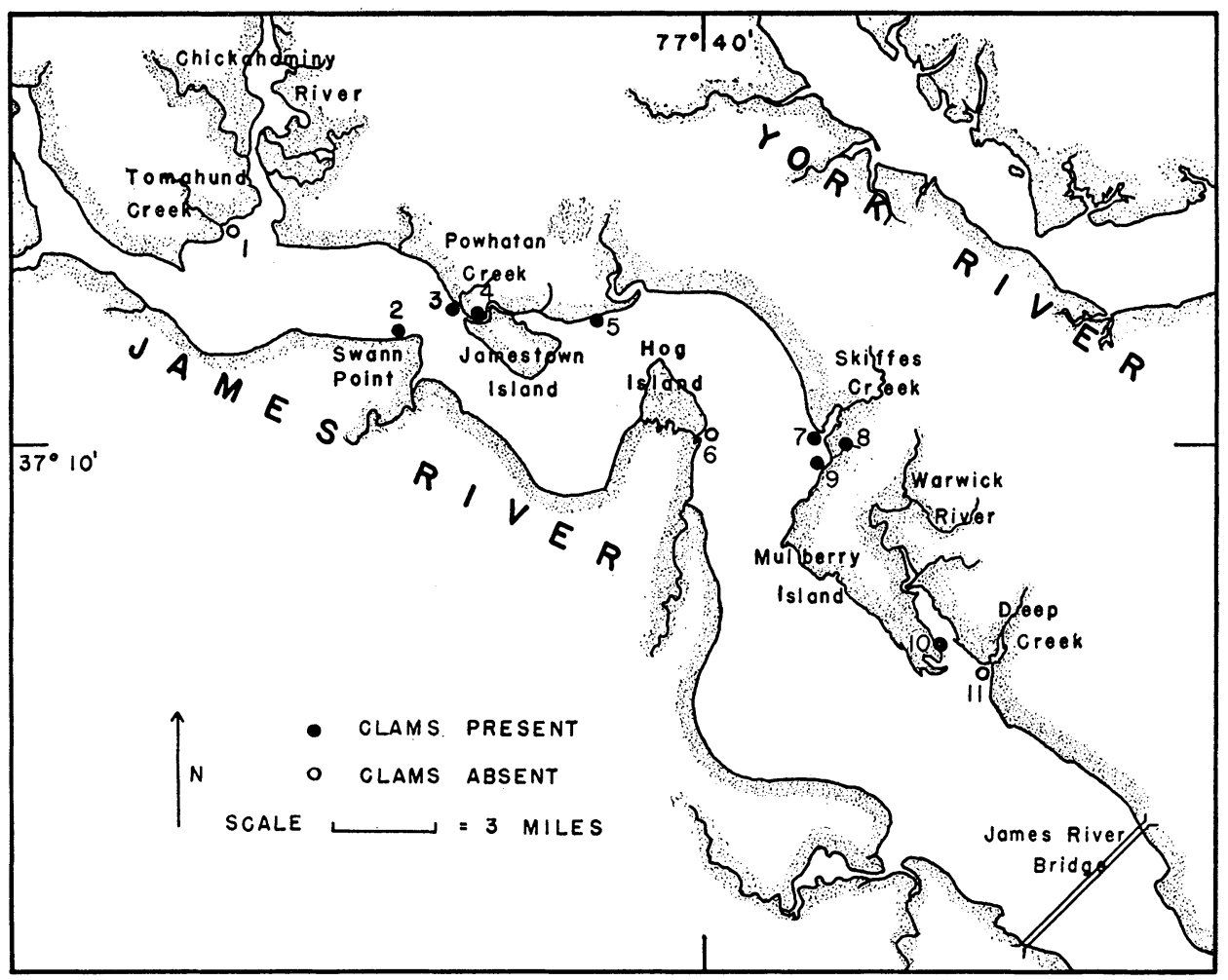

FIg. 1. Map of James River showing collecting stations.

silt with a distinct marsh odor. An accumulation of trash on the creek and the proximity of warehouses suggested polution. Stations: Creek at Ft. Eustis (8).

3. In crevices of riprap beach. Clams were found wedged between and under rocks and only slightly imbedded in the sparse soil. The species was more abundant here than at any other habitat examined; half a dozen clams could be found in an area two feet square. It was fairly obvious that these clams had set and grown in the rock crevices, for the beach below was loose sand and there was no evidence that they had washed in from elsewhere in the vicinity. Stations: Riprap beach at upper end of Mulberry Island (9).

TABLE I. Collections of Polymesoda in Virginıa

\begin{tabular}{l|c|c|c|c|c}
\hline \hline \multicolumn{1}{c|}{ Place } & $\begin{array}{c}\text { Station } \\
\text { number }\end{array}$ & Date & $\begin{array}{c}\text { Number of } \\
\text { clams } \\
\text { collected }\end{array}$ & $\begin{array}{c}\text { Mean. } \\
\text { length } \\
\text { (mm.) }\end{array}$ & $\begin{array}{c}\text { Length } \\
\text { range } \\
\text { (mm.) }\end{array}$ \\
\hline Swann Point (Hoffman) & 2 & 7 Apr. 1947 & 6 valves & - & - \\
Swann Point (Morrison) & 2 & 20 Apr. 1947 & many & - & - \\
Powhatan Creek & 3 & 5 Apr. 1949 & shells only & -36 & $27-46$ \\
Treasure Island & 5 & 3 Mar. 1949 & 10 & 36 & $12-37$ \\
Treasure Island & 4 & 12 Mar. 1949 & 17 & 28 \\
Back Creek & 8,9 & 7 Mar. 1949 & 15 & 31 & $14-44$ \\
Skiffes Creek Area & 8 & 25 May 1949 & 38 & 30 & $11-48$ \\
Skiffes Creek Area & 7 & 25 May 1949 & 32 & 33 & $14-42$ \\
Skiffes Creek Area & 9 & 25 May 1949 & 30 & 35 & $32-39$ \\
Skiffes Creek Area & 10 & 25 May 1949 & 7 & 31 & $15-49$ \\
Lower Mulberry Island & & & 159 & 31 & $11-49$ \\
\hline \multicolumn{1}{|c|}{ All samples } & & & & & \\
\hline
\end{tabular}




\section{Discussion}

While these habitats are superficially quite different, they have at least two common characteristics :

(a) all offer protection from the mechanical action of tides and currents

(b) all are intertidal and are exposed to the air at most low tides.

Conditions of low oxygen in the substratum do not seem to offer any barriers to Polymesoda. Clams were kept several months without dying in small bowls with little change of water and often with the substratum nearly dry. They are well called marsh clams, although, as indicated by Van der Schalie, the species will live for some time in sea water. Their ability to maintain a position in the substratum seems definitely limited despite a well-developed foot. The most essential requirement of the habitat seems to be a moderate amount of protection from the action of waves.

There is no reason to suspect that Polymesoda has been introduced into the James River in recent years. Its absence from previous lists reflects the general lack of faunal information in Virginia particularly in brackish waters. Poly- mesoda is limited to slightly brackish waters and the family is a brackish to freshwater transition group. The species now has a discontinuous distribution and extension of its range appears to be precluded by salt and freshwater barriers. Because the habitats are very limited in area, a local population, such as occurs in the James River, is relatively small in total numbers. This population has probably been isolated from those of other river systems to the south since sometime in the Pleistocene. If this is true the species is interesting from the genetic and evolutionary standpoint.

\section{Literature Cited}

Van der Schalie, Henry. 1933. Notes on the brackish water bivalve, Polymesoda caroliniana (Bosc). Univ. Mich. Occ. Pap. Mus. Zool., 11 (258) : 1-8.

Jay D. Andrews
Catherine CoOK
Virginia Fisheries Laboratory,
Gloucester Point, Virginia
Alexandria Health Center,
Alexandria, Virginia

Jay D. Andrews

ABORATORY, Alexandria, Virginia

\section{A GROUND PLAN FOR A BIOLOGICAL RESEARCH PLANT}

Thirty-five years ago the writer undertook to control temperature, atmospheric moisture, evaporation, air movement, and so far as possible, light, in a large series of experiments. The biological material was an hemipterous insect which feeds on plants. Constant and variable conditions were used, the latter simulating average days, and supplemented with out-ofdoor checks and observations.

The glass-roofed room used for this work was attached to the east end of an ordinary building which cast shadows over the air conditioned experimental units beginning soon after 1:00 P. M. for some of them and later for others. Some of the units fell into full shadow in the early afternoon, others later. Due to the varying position of the sun and the necessity of arrangement of the units, this could not be avoided. The shadows interfered with all controls and gave unequal effects on the food plants living under reduced light due to several thicknesses of glass. The arrangement of glass-roofed space with reference to use in experiments with animals has evidently been an outgrowth of the idea that too much sunlight is usually available and that it may be reduced by haphazard shadows with no ill effects. Most institutions have haphazard arrangements resulting from architectural plans. A scientific approach calls for symmetrical and uniform sun and sky exposure. Otherwise the investigator cannot control light and other sun and sky radiations without shutting them off altogether. This unfortunately renders the control of other factors easier. Symmetrical lighting and known periods of sun exposure become scientifically essential the moment long exposure to weak ultraviolet light has been demonstrated to act as a reproductive stimulus (Sabrosky, Larson, and Nabours 1933; Marshall and Bowden 1934; Bailey 1950), or to be important in the control of populations (Shelford 1951). Some recent investigations have stressed duration of sunshine in connection with bovine reproduction (Mercier and Salisbury 1947). Radiation control for plants and photoperiodism for birds and plants need no comment.

As an outgrowth of his experiences, the writer has drawn a rough outline of a plan for a biological plant in which some of the neglected factors can be controlled (Fig. 1). This is based on location on a nearly level plane at $40^{\circ} \mathrm{N}$. Latitude. The objective is to provide space for glass-roofed houses, outside areas for kennels and cages, gardens, and ponds, including an area of $200 \mathrm{ft}$. sq. (a little less than $40,000 \mathrm{sq}$. $\mathrm{ft}$.) which will receive all the hours of sunlight which are available above the tops of trees and buildings $70 \mathrm{ft}$. high. A larger space not 